Politik Indonesia: Indonesian Political Science Review 1 (2) (2016) 196-211

Politik Indonesia

Indonesian Political Science Review

http://journal.unnes.ac.id/nju/index.php/JPI

\title{
Evaluasi Pilkada Pelaksanaan Pilkada Serentak Tahun 2015
}

Pangi Syarwi Chaniago ${ }^{1 凶}$

${ }^{1}$ Universitas Islam Negeri Syarif Hidayatullah, Indonesia

\begin{tabular}{|c|c|}
\hline Info Artikel & Abstrak \\
\hline $\begin{array}{l}\text { Sejarah Artikel: } \\
\text { Diterima } 11 \text { April } 2016 \\
\text { Disetujui } 15 \text { Juni } 2016 \\
\text { Dipublikasi } 15 \text { Juli } 2016\end{array}$ & $\begin{array}{l}\text { Tujuan dari penelitian ini untuk mengevaluasi penyelenggaraan pilkada serentak tahap } \\
\text { pertama tahun 2015, dalam rangka peningkatan kualitas demokrasi. Penelitian } \\
\text { menggunakan metode kualitatif. Adapun hasil penelitian yaitu; (1) pilkada serentak belum } \\
\text { efisien; (2) pilkada serentak belum mampu meningkatkan partisipasi politik; (3) pilkada }\end{array}$ \\
\hline $\begin{array}{l}\text { Keywords: } \\
\text { Quality of Democracy; } \\
\text { Direct District Heads } \\
\text { Election; District Head } \\
\text { Candidates; Evaluation }\end{array}$ & $\begin{array}{l}\text { bakal pasangan calon kepala daerah belum terbuka dan transparan; (5) pembiayaan } \\
\text { pilkada serentak tidak (tepat) dibebankan ke APBD; (6) MK menolak mengadili sengketa } \\
\text { hasil pilkada jika selisih suara lebih dari } 2 \% \text {, melukai rasa keadilan; (7) fenomena } \\
\text { munculnya calon tunggal kepala daerah akibat regulasi wajib mundur bagi PNS, } \\
\text { TNI/Polri, DPR, DPD, dan DPRD. }\end{array}$ \\
\hline
\end{tabular}

\begin{abstract}
$\overline{\text { This study was carried out to evaluate the enforcement of the first direct district heads }}$ election in 2015, in order to promote the quality of democracy. This study applied qualitative method. There were several findings on this study; (1) direct district heads election has not been efficient yet; (2) direct district heads election has not been able to promote political participation; (3) direct district heads election has not been able to shut off money politic; (4) recruitment the election of district head candidates has not been transparant; (5) financing of direct election was not charged (appropriate) to Regional Government Budget; (6) Constitutional Court refused to adjudicate the dispute of election results if the margin of ballot more than $2 \%$, it broke sense of justice; (7) the phenomenon of the emergence of a single candidate for district heads due to regulations, the must withdraw from candidacy for they were civil servants, military/police, House of Representatives, Regional Representative Board and Regional House of Representatives.
\end{abstract}

(C) 2016 Universitas Negeri Semarar

\footnotetext{
Alamat korespondensi:

Jl. Ir. H. Juanda No 95, Ciputat, Tangerang, Indonesia. Email: pangisyarwi@ gmail.com
}

ISSN $2477-8060$ 


\section{Pendahuluan}

Pemilu adalah kenduri demokrasi yang menjadi landasan politik bangsa dan negara dalam membangun masa depan yang lebih baik. Pemilu sebagai pilar demokrasi mengantarkan bangsa dan negara dalam meraih demokrasi dan membangun peradabannya. Selain itu, pemilu juga sebagai momentum evaluatif yang sangat penting bagi sebuah rezim kekuasaan dalam mewujudkan cita- cita negara kemerdekaan.

Praktek demokrasi tidak bisa dilepaskan dari proses penyelenggaraan pemilihan umum. Pentingnya nilai demokrasi yang selalu dikembangkan yaitu masalah freedom, autonomy, equality, representative, majority rule citizenship. Pencapaian demokrasi kita masih jauh dari nilai di atas, pengalaman demokrasi kita belum menuju demokrasi substansial, namun hanya sebatas demokrasi prosedural yaitu ritual pencitraan pemilu sekali lima tahun dalam memilih pemimpin, padahal demokrasi tidak hanya sekedar prosedural pemilihan (Zuhro, 2012).

Membangun sistem pemilu dibutuhkan nilai etika. Dengan berbagai teori yang kita miliki dan pengalaman perpolitikan di Indonesia selama ini dapat kita gunakan untuk membangun demokrasi dengan menggunakan prinsip nilai yang kita yakini bersama. Kekuasaan tanpa etika akan menjadi lemah karena tidak ada legitimasi, maka kekuasaan harus dengan etika supaya bisa di kontrol (Mar'iyah, 2012).
Penyelenggaraan pemilihan kepala daerah serentak tahun 2015 meninggalkan banyak catatan. Dibutuhkan perbaikan penyelenggaraan pilkada serentak dimulai dengan merevisi Undang-Undang Nomor 8 Tahun 2015 tentang Pemilihan Gubernur, Bupati, dan Wali Kota. Revisi undang-undang pilkada dilakukan dalam rangka mewujudkan pilkada yang transparan, jujur dan demokratis. Revisi harus mampu menjawab apa yang menjadi kelemahan dan kekurangan pilkada serentak tahun 2015 dalam rangka peningkatan mutu demokrasi di daerah.

Revisi undang-undang No. 8 Tahun 2015, harusnya mengambil fokus terhadap persoalan yang berpotensi merusak makna hakiki penyelenggaraan pilkada. Apalagi, DPR sebagai pembentuk UU berkewajiban menjaga makna hakiki pilkada serentak yang demokratis dalam Pasal 18 Ayat (4) UUD 1945. Kewajiban serupa juga menjaga asasasas pemilu yang bersifat langsung, umum, bebas, rahasia, jujur, dan adil dalam Pasal 22E Ayat (1) UUD 1945. Undang-Undang No. 8 Tahun 2015 merupakan revisi atas undangundang sebelumnya yakni Undang-Undang Nomor 1 Tahun 2015 tentang penetapan Peraturan Pemerintah Pengganti UndangUndang Nomor 1 Tahun 2014 perihal Pemilihan Gubernur, Bupati dan Walikota menjadi Undang-Undang. Namun tetap saja masih terdapat kelemahan dalam UndangUndang Nomor 8 Tahun 2015. Produk undang-undang di atas masih meninggalkan beberapa persoalan mendasar. Dalam 
praktiknya banyak ditemukan kelemahan dan kekurangan.

Materi UU Nomor 1 Tahun 2015 mengandung banyak masalah, baik dari sisi redaksional, sistematika maupun substansi. Jika dilihat dari pengaturan aktor, sistem pemilihan, manajemen atau tahapan pelaksanaan dan penegakan hukum, kekurangan dan kelemahannya semakin nyata. Maka wajar saja muatan Undang-Undang Nomor 8 Tahun 2015 yang cikal bakalnya dari UU No. 1 Tahun 2015 mengandung banyak kelemahan dan kekurangan baik dari segi sistematika maupun substansi, maka undang-undang tersebut mesti direvisi. ${ }^{80}$

Fokus tulisan ini adalah membahas evaluasi pelaksanaan pilkada serentak tahap pertama tahun 2015. Hasil evaluasi ini dapat menjadi catatan untuk perbaikan kualitas pelaksanaan pilkada serentak pada masa yang akan datang.

\section{Kajian Pustaka}

Metodologi

Penelitian ini menggunakan metode kualitatif dengan sumber data primer dan sekunder. Sumber primer diperoleh melalui wawancara. Sumber informan adalah peneliti Perkumpulan Untuk Pemilu dan Demokrasi (Perludem). Parameter pemilihan narasumber yaitu memahami dan menguasai permasalahan pemilu. Tahapan pendekatan penulisan dalam

80 Pandangan terkait dengan kekurangan dan kritik terhadap UU Pilkada misalnya dapat dilacak dari laporan kajian Koalisi Masyarakat Sipil Untuk Revisi Undang-Undang Pilkada. (2015). Menuju Pilkada Serentak Nasional 2021. Jakarta: Perludem penelitian dengan menggambarkan dan menganalisis secara mendalam terhadap objek yang diteliti, dan melakukan kajian analisa yang mendalam terkait evaluasi pelaksanaan pilkada serentak di tahun 2015.

Sumber sekunder diperoleh dari kajian pustaka yakni kumpulan buku, jurnal, artikel, majalah dan laporan penelitian. Pendekatan ini dipilih karena lebih mampu menemukan fakta dalam melihat antara realitas di lapangan dengan teori. Untuk menjawab dan menyimpulkan pemecahan permasalahan penelitian dilakukan dengan langkah-langkah pengumpulan dan penyusunan data yang diperoleh dari sumbersumber dokumentasi dan studi literatur.

\section{Temuan dan Diskusi}

Pemilu serentak (concurrent elections) secara sederhana dapat didefinisikan sebagai sistem pemilu yang melangsungkan beberapa pemilihan pada satu waktu secara bersamaan. Jenis-jenis pemilihan tersebut mencakup pemilihan eksekutif dan legislatif di beragam tingkat, yang terentang dari tingkat nasional, regional hingga pemilihan di tingkat lokal. Di negaranegara anggota Uni Eropa, pemilu serentak termasuk menyelenggarakan pemilu untuk tingkat supra-nasional, yakni pemilihan anggota parlemen Eropa secara bersamaan dengan pemilu nasional, regional atau lokal (Mattila, 2003).

Disinilah tesis Shugart tentang bekerjanya sistem pemilu dalam membentuk 
pemerintahan efektif dalam sistem presidensial, perlu mendapat perhatian. ${ }^{81}$ Menurut Shugart, jika waktu penyelenggaraan pemilu presiden diserentakkan (simultan) dengan pemilu legislatif akan menimbulkan coattail effect, yaitu (hasil) pemilihan presiden akan mempengaruhi (hasil) pemilihan anggota legislatif. Artinya, pemilih akan memilih presiden sekaligus parpol (koalisi parpol) pendukung presiden (Lijphart, 1994).

\section{Beragam faktor mempengaruhi} penyelenggaraan pemilu serentak, maka terdapat beberapa varian yang sebagian sudah diterapkan dan beberapa lagi masih sifatnya hipotetis. Sistem pemilu serentak sudah diterapkan di banyak negara demokrasi. Sistem ini ditemukan tidak hanya di negaranegara yang telah lama menerapkan sistem demokrasi seperti Amerika Serikat dan negara-negara di kawasan Eropa Barat, melainkan juga ditemukan di banyak negara demokrasi yang relatif lebih muda seperti negara-negara demokrasi di kawasan Amerika Latin, dan Eropa Timur. ${ }^{82}$

Secara umum, untuk konteks Indonesia dengan mendasarkan pada varian secara empirik maupun hipotetis, terdapat

\footnotetext{
${ }^{81}$ Tesis Shugart ini ternyata berlaku di Brazil setelah mereka melakukan perubahan jadwal pemilu, yaitu dengan menyerentakkan waktu penyelenggaraan pemilu presiden dan pemilu anggota legislatif. Inilah yang menjadi salah satu faktor mengapa pasca jatuhnya rezim militer pada 1984 dan jatuhnya presiden terpilih pertama oleh Senat dan DPR, Brazil kemudian mampu menjaga stabilitas politik sekaligus menciptakan pemerintahan efektif sehingga satu dekade kemudian Brazil menjadi raksasa ekonomi dunia.

82 Samuels, D. Concurrent Elections, Discordant Results: Presidentialism, Federalism, and Governance in Brazil," dalam Comparative Political Studies 33 (1): $1-20$.
}

setidaknya enam model pemilu serentak yang bisa diterapkan. Pertama, pemilu serentak sekaligus serentak, satu kali dalam lima tahun, untuk semua posisi publik di tingkat nasional hingga kabupaten/kota. Pemilu ini meliputi pemilihan legislatif (DPR, DPD, DPRD Provinsi dan DPRD Kab/Kota), pemilihan presiden, serta pilkada. Ini seringkali disebut dengan pemilihan tujuh kotak atau pemilu borongan.

Kedua, pemilu serentak hanya untuk seluruh jabatan legislatif (pusat dan daerah) dan kemudian disusul dengan pemilu serentak untuk jabatan eksekutif (pusat dan daerah). Dalam model clustered concurrent election ini, pemilu untuk DPR, DPD, DPRD Propinsi dan DPRD Kab/Kota dilaksanakan seperti selama ini dilakukan bersamaan sesuai waktunya, dan kemudian diikuti pemilu presiden, gubernur dan bupati/walikota beberapa bulan kemudian.

Ketiga, pemilu serentak dengan pemilu sela berdasarkan tingkatan pemerintahan, di mana dibedakan waktunya untuk pemilu nasional dan pemilu daerah/lokal (concurrent election withmidterm election). Dalam model ini pemilu anggota DPR dan DPD bersamaan pelaksanaannya dengan pemilu presiden. Sementara pemilu DPRD provinsi, kabupaten/kota dilakukan bersamaan dengan pemilihan gubernur dan bupati/walikota, dua atau tiga tahun setelah pemilu nasional.

Keempat, pemilu serentak tingkat nasional dan tingkat lokal yang dibedakan 
waktunya secara interval (concurrent election with regional-based concurrent elections). Dalam model ini, pemilihan presiden dan pemilihan legislatif untuk DPR dan DPD dilakukan bersamaan waktunya. Kemudian pada tahun kedua diadakan pemilu serentak tingkat lokal untuk memilih DPRD Provinsi dan Kabupaten/Kota serta pemilihan Gubernur dan Bupati/Walikota berdasarkan pengelompokan region atau wilayah kepulauan tertentu. Misal tahun kedua khusus untuk wilayah Pulau Sumatera. Kemudian disusul tahun ketiga untuk wilayah pulau Jawa, dan tahun keempat untuk wilayah Bali dan Kalimantan, dan tahun kelima untuk wilayah sisanya.

Kelima, adalah pemilu serentak untuk memilih anggota DPR, DPD, dan DPRD serta Presiden dan Wakil Presiden dan kemudian diikuti setelah selang waktu tertentu dengan pemilu eksekutif bersamaan untuk satu provinsi. Dalam pemilu ini, pemilu serentak tingkat lokal hanyalah untuk memilih Gubernur, Bupati dan Walikota secara bersamaan di suatu provinsi, dan jadwalnya tergantung dari siklus pemilu lokal di masingmasing provinsi yang telah disepakati. Dengan model ini maka setiap tahun masingmasing partai akan selalu bekerja untuk mendapatkan dukungan dari pemilih dan pemerintah, serta partai politik dapat selalu dievaluasi secara tahunan oleh pemilih.

Keenam, adalah pemilu serentak tingkat nasional yang kemudian diikuti dengan pemilu serentak di masing-masing provinsi berdasarkan kesepakatan waktu atau siklus pemilu lokal di masing-masing provinsi tersebut. Dengan model concurrent election with flexible concurrent local elections ini maka pemilihan presiden dilakukan serentak dengan pemilihan legislatif untuk DPR dan DPD. Kemudian setelahnya tergantung dari siklus maupun jadwal pemilu lokal yang telah disepakati bersama diadakan pemilu serentak tingkat lokal untuk memilih Gubernur, Bupati, dan Walikota serta memilih anggota DPRD Provinsi dan Kabupaten/Kota di suatu provinsi, dan kemudian diikuti dengan pemilu serentak lokal yang sama di provinsi-provinsi lainnya sehingga bisa jadi dalam setahun ada beberapa pemilu serentak lokal di sejumlah provinsi (Supriyanto, dkk, 2013).

Dengan demikian, mulai dari Presiden, Gubernur, Bupati dan Walikota serta Anggota DPR, DPD, dan DPRD seluruh Indonesia dipilih secara serentak melalui satu waktu pemilihan umum nasional. Jika pemilihan nasional yang bersifat total itu dipandang tidak realistis, maka tersedia pilihan kedua, yaitu dapat diusulkan dilakukannya pemilihan yang bertingkat. Pemilihan umum dilakukan dalam tiga tingkatan yang masing-masing dimaksudkan untuk memilih pejabat eksekutif dan legislatif setempat, yaitu (i) pemilihan umum pusat untuk memilih Presiden/Wakil Presiden, Anggota DPR, dan anggota DPD; (ii) pemilihan umum provinsi untuk memilih Gubernur dan anggota DPRD Provinsi; dan (iii) pemilihan umum kabupaten/kota untuk 
memilih Bupati dan anggota DPRD Kabupaten serta Walikota dan anggota DPRD Kota, yang dilakukan serentak di tingkat pemerintahan masing-masing sesuai dengan jadwal kenegaraan yang ditetapkan. ${ }^{83}$

Berdasarkan Pasal 201 ayat (1) UU No 1/2015, KPU menyelenggarakan pilkada serentak tahap pertama pada tanggal 9 Desember 2015. Daerah yang mengikuti pilkada serentak tahap pertama meliputi 9 provinsi, 237 Kabupaten dan 40 Kota. Jumlah total mencakup 286 daerah yang merupakan $52,2 \%$ dari jumlah daerah provinsi dan kabupaten kota di seluruh Indonesia. Masa jabatan pasangan calon terpilih akan berakhir pada Agustus 2021, di mana mereka akan melanjutkan atau diganti oleh hasil pilkada serentak nasional pada Juni 2021 (Supriyanto, 2011).

Pilkada serentak tahap dua pada Juni 2017 diperuntukkan bagi daerah yang akhir masa jabatan kepala daerah yang jatuh sepanjang September 2016 hingga Agustus 2017. Masa jabatan pasangan calon terpilih akan berakhir pada Agustus 2021, di mana mereka akan melanjutkan atau diganti oleh hasil pilkada serentak nasional pada Juni 2021. Dengan demikian, masa jabatan mereka tidak genap 5 tahun. Pilkada Juni 2017 akan diikuti 5 provinsi, 51 kabupaten, dan 9 kota atau meliputi 11,9\% daerah di Indonesia.

${ }^{83}$ Asshiddiqie, Jimly . Pemilihan Umum Serentak dan Penguatan Sistem Pemerintahan. (Online). (http://www. jimly.com/makalah/namafile/173/PEMILIHAN_UMUM _SERENTAK.pdf diakses 2 April 2016)
Pilkada serentak tahap tiga pada Juni 2018 diperuntukkan bagi daerah yang akhir masa jabatan kepala daerahnya jatuh sepanjang September 2017 hingga Desember 2019. Masa jabatan pasangan calon terpilih akan berakhir pada Agustus 2021, di mana mereka akan melanjutkan atau diganti oleh hasil pilkada serentak nasional pada Juni 2021. Dengan demikian, masa jabatan mereka tidak genap 5 tahun. Pilkada serentak Juni 2018 akan diikuti 20 provinsi, 128 kabupaten dan 49 kota yang meliputi $35,9 \%$ dari keseluran daerah di Indonesia.

Ini kali pertama penyelenggaraan pilkada serentak di 286 daerah, tidak berlebihan bila disebut pilkada serentak terbanyak di dunia dalam kurun waktu satu hari yakni memilih gubernur dan bupati/walikota secara langsung. Indonesia mesti berbangga dalam proses pencapaian dan kemajuan demokrasi kita, walaupun di sana sini masih terdapat beberapa kekurangan.

\section{Efisiensi Pilkada Serentak}

Pilkada serentak seharusnya bisa menekan biaya penyelenggaraan pemilu yang selama ini boros. Kalau di telaah secara kritis, desain pilkada serentak tahap pertama tahun 2015 sebetulnya belum memenuhi unsur penghematan. Padahal dari awal salah satu yang menjadi latar belakang dilaksanakan pilkada serentak dalam rangka penghematan terhadap penyelenggaraan pilkada. Pandangan yang sama dinyatakan peneliti Perludem bahwa pilkada serentak tahap 
pertama belum mencerminkan semangat efisiensi dan tetap saja boros dari segi penggunaan anggaran penyelenggaraan.

"Segi efisensi pada pilkada tahap pertama belum bisa kita lihat, desain pilkada serentak itu masih berjarakan. Misalnya di Jawa Barat ada delapan daerah yang melaksanakan pilkada serentak namun tidak dibarengkan bersamaan dengan pemilihan gubernur. Kalau waktu penyelenggaraan pemilihan gubernur berbeda dengan waktu penyelenggaraan pemilihan bupati dan wali kota, maka biaya politiknya otomatis dua kali. Itu artinya, gaji penyelenggara PPS, PPK tingkat desa dan kecamatan akan di bayar dua kali. Pertanyaan yang menggelitik bagaimana agar penyelenggaraan pilkada serentak bisa efisien? Desain pilkada serentak yang efisien apabila pemilihan gubernur, walikota, bupati, DPRD provinsi dan DPRD kab/kota dilaksanakan bersamaan atau berbarengan. Jadi, kalau hanya pemilihan bupati dan wali kota saja yang serentak, sementara pelaksanaan pemilihan gubernurnya berbeda maka tidak akan terlalu signifikan menekan atau memanimilisir biaya penyelenggaraan pilkada". ${ }^{84}$

Maka sesungguhnya biaya yang paling besar dalam penyelenggaraan pemilu itu adalah anggaran belanja gaji penyelenggara. Kalau seandainya pilkada gubernur, bupati/walikota dan DPRD provinsi dan kabupaten/kota dilaksanakan secara bersamaan dalam satu waktu dengan

84 Wawancara dengan Heroik Pratama (Peneliti Perludem Divisi Pilkada, 4 Februari 2016, Pukul 10.00 WIB, di Kantor Perludem Jalan Tebet Timur IV A, Daerah Khusus Ibukota Jakarta. penyelenggaranya hanya satu kepanitian, maka bisa dipastikan pilkada serentak berjalan efisien. Bisa kita bayangkan penghematannya, penyelenggara hanya mengeluarkan untuk satu kali gaji saja dalam satu paket. Jadi pilkada serentak tahap pertama tahun 2015 masih belum efisien.

Hal sama juga disampaikan direktur eksekutif Perludem, Titi Anggraini, bahwa efisiensi dari pilkada serentak baru bisa tercapai apabila dalam satu provinsi, pilkadanya serentak dilaksanakan mulai dari pemilihan gubernur, bupati atau walikota dalam satu provinsi. Sebagai contoh, di Provinsi Banten dari delapan kota/kabupaten hanya empat daerah yang menyelenggarakan pilkada serentak. Kalau sekarang di Banten ada Tangerang Selatan, Serang, Cilegon, dan Pandeglang yang penyelelenggaran pilkada jalan sendiri-sendiri dan ditambah lagi biaya dibebankan ke APBD, jadi tidak efisien. Efisiensi itu bisa tercapai apabila pemilihan gubernur, bupati atau walikota bisa bersamaan karena akan ada efisiensi dalam honor untuk penyelenggara dan efisiensi logistik pilkada. Efisiensi baru bisa terjadi seperti di Sumatera Barat karena tahun ini ada pilkada provinsi dan kabupaten/kota dilebih dari 10 kabupaten/kota, maka efisiensi dapat terkonfirmasi. ${ }^{85}$

Jadi, salah satu indikator pilkada serentak akan efisien apabila waktu

85 Anggraini, T. 16 November 2015. Efisiensi penyelenggaraan Pilkada Serentak 2015 Belum Bisa Tercapai. (Online), (http://www.republika.co.id/berita/ nasional/pilkada/15/11/16/nxwawg335-efisiensi-pilkadaserentak-belum-tercapai, diakses 30 Maret 2016) 
penyelenggaraan gubernur, bupati, walikota adalah sama. Memang tidak mudah membuat pilkada serentak, konsekuensinya ada beberapa kepala daerah yang dipotong masa jabatannya, nanti akan ada resistensi dari kepala daerah lainnya, dan pada akhirnya bisa menjadi polemik.

Selain itu, desain penghematan pemilu juga bisa dari mempersingkat jenjang proses rekapitulasi. UU No.8 Tahun 2015 memang sudah mengatur sedemikian rupa, rekapitulasi penghitungan suara secara berjenjang sesuai tingkatannya, dimulai di tingkat panitia pemungutan suara (PPS), kemudian naik ke tingkat panitia pemilihan kecamatan (PPK) lalu naik ketingkat KPU Kabupaten Kota, lalu naik ke tingkat KPU Provinsi, dan rekap secara nasional di KPU RI. Rekapitulasi pola berjenjang, misalnya dibawa ke desa di rekap oleh PPS kemudian dibawa ke kecamatan di rekap lagi oleh PPK, ini cenderung tidak efisien. Selain rekapitulasi suara berlapis tidak efisien juga rentan terjadi penyalahgunaan dan penyelewengan karena lamanya waktu dan proses rekapitulasi. Jenjang rekapitualisi yang berlama-lama menunjukkan sinyal yang tidak efisien dan tidak transparan.

\section{Partisipasi Politik}

Pemilu serentak sebetulnya punya korelasi meningkatkan partisipasi pemilih. Sebab masyarakat datang ke TPS cukup satu kali untuk memilih presiden, DPD, DPR, DPRD Provinsi dan DPRD kab/kota yang dilaksanakan serentak, sehingga masyarakat tidak jenuh atau bosan datang berkali-kali ke TPS. Walaupun dampak pemilu serentak dan hubungannya dengan tingkat partisipasi pemilih tidak sebesar pengaruh penerapan sistem wajib memilih (compulsory voting), namun sejumlah bukti menunjukkan bahwa ada korelasi pengaruh sistem pemilu serentak terhadap partisipasi pemilih lebih tinggi. ${ }^{86}$

Fakta di beberapa pilkada serentak tahap pertama tahun 2015, justru berbalik dari situasi idealnya. Walaupun tidak secara keseluruhan, namun tetap ada beberapa daerah tingkat partisipasi pemilih rendah dalam penyelenggaraan pilkada serentak. Masih ada daerah yang tingkat partisipasinya dibawah 50 persen. Salah satu penyebabnya adalah karena kurang optimalnya sosialisasi penyelenggaraan pemilu. Selanjutnya, akibat aturan KPU yang memperketat pengunaan alat peraga dalam rangka menghemat biaya pemilu, sehingga pilkada serentak tidak terlalu semarak apabila dibandingkan dengan pilkada-pilkada sebelumnya.

${ }^{86}$ Penelitian Electoral Research Institute bekerjasama dengan Lembaga Ilmu Pengetahuan Indonesia dalam bentuk Position Paper dengan judul "Pemilu Nasional Serentak 2019". Penelitian tersebut mengkaji pemilu serentak tingkat nasional dan tingkat lokal yang dibedakan waktunya secara interval (concurrent election with regional-based concurrent elections). Dalam model ini, pemilihan presiden dan pemilihan legislatif untuk DPR dan DPD dilakukan bersamaan waktunya. Kemudian pada tahun kedua diadakan pemilu serentak tingkat lokal untuk memilih DPRD Propinsi dan Kabupaten/Kota serta pemilihan Gubernur dan Bupati/Walikota berdasarkan pengelompokan region atau wilayah kepulauan tertentu. Misal tahun kedua khusus untuk wilayah Pulau sumatera. Kemudian disusul tahun ketiga untuk wilayah pulau Jawa, dan tahun keempat untuk wilayah Bali dan Kalimantan, dan tahun kelima untuk wilayah sisanya. 
Pembiayaan empat jenis atribut kampanye yang diatur KPU banyak dikritik karena dianggap sebagai salah satu akar persoalan menurunnya tingkat partisipasi masyarakat (vote turn out) di pilkada serentak 2015. Selain itu, penurunan tingkat partisipasi juga disebabkan oleh faktor lain seperti kejenuhan pemilih, tidak ada figur alternatif yang ditawarkan, hingga tidak memilih karena urusan teknis dan administratif.

Debat publik kurang optimal sebagai panggung membentuk opini publik untuk memperkenalkan kandidat ke pemilih dalam hal menguji kualitas gagasan, visi-misi, narasi kepemimpinan sampai dengan program yang ditawarkan. Realitasnya selama ini debat publik hanya sebatas ritualisme politik belaka namun tidak mampu membangkitkan animo masyarakat untuk datang ke Tempat Pemilihan Suara (TPS).

\section{Mahar dan Politik Uang}

Politik uang (money politics) baik dalam pencalonan maupun pemungutan suara masih banyak terjadi dalam pelaksanaan pilkada serentak tahun 2015. Politik uang adalah praktek destruktif (menyimpang) yang merusak mutu demokrasi. Undang-undang pilkada selama ini belum mampu meminimalisasi potensi politik uang.

Salah satu dugaan bentuk kecurangan money politics terjadi di delapan kabupaten kota di Provinsi Maluku Utara (Malut). Adanya 79 laporan yang diterima Badan Pengawas Pemilihan Umum (Bawaslu) Malut pasca pemungutan dan penghitungan suara pilkada serentak 9 Desember 2015 menguatkan dugaan masih banyaknya politik uang. ${ }^{87}$ Di Bengkulu sebanyak 7 dari 13 kasus dugaan money politics yang diterima Panwas Kabupaten Seluma, Bengkulu, selama pilkada dapat diteruskan ke Penegakan Hukum Terpadu Pemilihan Umum (Gakkumdu) untuk diproses sesuai hukum yang berlaku. Sedangkan enam kasus lagi tidak dapat diproses atau diteruskan oleh Panwas ke Gakkumdu setempat, karena tidak memenuhi syarat pidana umum. ${ }^{88}$

Kasus di Kabupaten Karo misalnya, seorang pelaku money politics diamankan Panitia Pengawas Pemilu (Panwaslu) Kecamatan Dolat Rakyat, Sumatera Utara, oknom tertangkap membagikan uang senilai Rp150 ribu kepada masyarakat guna mendukung salah satu calon di Pilkada Serentak 2015 Kabupaten Karo. Pihak Panwaslu Kecamatan Dolat Rakyat menyita barang bukti berupa data penerima uang yang ditandatangani di atas materai $\mathrm{Rp} 6.000$. Pelaku mengaku tidak mengetahui tentang politik uang tersebut. Berdasarkan keterangan pelaku yang diketahui bernama Heri Bangun, pembagian uang dilakukan atas perintah seorang kawannya yang menyerahkan uang

87 Bawaslu. 14 Desember 2015. Bawaslu Malut Terima 79 Laporan Dugaan Money Politic. (Online), (http://www.jpnn.com/read/2015/12/14/344509/Bawaslu -Malut-Terima-79-Laporan-Dugaan-Money-Politic-, diakses 4 April 2016)

${ }^{88}$ Panwas. 18 Desember 2015. 7 kasus dugaan politik uang pilkada seluma diproses gakkumdu. (Online), (http://www.beritasatu.com/nasional/333138-7-kasusdugaan-politik-uang-pilkada-seluma-diprosesgakkumdu.html, diakses 2 April 2016) 
Rp1,5 juta untuk dibagikan ke 10 orang supaya mendukung calon kepala daerah nomor 4 atas nama Layari Sinukaban dan wakilnya Ramlan Tarigan.

Regulasi pelarangan praktik politik uang dijelaskan secara tegas dan keras dalam Pasal 47 Ayat (1) UU No 8 Tahun 2015 menyebutkan bahwa "Partai Politik atau gabungan Partai Politik dilarang menerima imbalan dalam bentuk apapun pada proses pencalonan Gubernur dan Wakil Gubernur, Bupati dan Wakil Bupati, serta Walikota dan Wakil Walikota". ${ }^{89}$ Sangat jelas sanksi bagi aktor dan oknum pelaku politik uang, di mana penyelenggara pilkada bisa men-diskualifikasi pasangan calon dan partai politik pengusul kehilangan hak mengajukan calon baru (Isra, 2016).

Penyelenggara pilkada harus mampu mengantisipasi money politics baik waktu proses pencalonan maupun ketika masa kampanye jauh sebelum pelaksanaan pilkada serentak. Di samping penyelenggara, idealnya praktek politik uang juga menjadi

89 Dalam ketentuan Pasal 47 UU No. 8 Tahun 2015 diubah sehingga berbunyi sebagai berikut: Pasal 47 Ayat (1) Partai Politik atau gabungan Partai Politik dilarang menerima imbalan dalam bentuk apapun pada proses pencalonan Gubernur dan Wakil Gubernur, Bupati dan Wakil Bupati, serta Walikota dan Wakil Walikota. Ayat (2) Dalam hal Partai Politik atau gabungan Partai Politik terbukti menerima imbalan sebagaimana dimaksud pada ayat (1), Partai Politik atau gabungan Partai Politik yang bersangkutan dilarang mengajukan calon pada periode berikutnya di daerah yang sama. Ayat (3) Partai Politik atau gabungan Partai Politik yang menerima imbalan sebagaimana dimaksud pada ayat (2) harus dibuktikan dengan putusan pengadilan yang telah memperoleh kekuatan hukum tetap. Ayat (4) Setiap orang atau lembaga dilarang memberi imbalan kepada Partai Politik atau gabungan Partai Politik dalam bentuk apapun dalam proses pencalonan Gubernur dan Wakil Gubernur, Bupati dan Wakil Bupati, serta Walikota dan Wakil Walikota. tanggung jawab semua stake holder untuk mengawasinya. Kalau kita membaca aturan dan regulasi, sudah banyak upaya dalam menekan perilaku politik uang dalam pilkada serentak. Misalnya larangan mahar politik dalam Pasal 47 Ayat (1) UU No 8 Tahun 2015 menyatakan bahwa partai politik/gabungan partai politik dilarang menerima imbalan dalam bentuk apa pun pada proses pencalonan kepala daerah. Salah satu bentuk sangsi tegas bagi calon kepala daerah yang terbukti memberi "mahar" kepada partai yakni akan di-diskualifikasi dan dilarang mencalonkan kembali pada pilkada periode berikutnya. Sedangkan, partai politik pengusung yang menerima setoran akan didenda 10 kali lipat dari dana yang diterima dari calon.

Sanksi pidana terhadap pelaku politik uang mestinya bisa dipraktekkan, baik bagi penerima maupun pemberi. Namun realita di lapangan politik uang masih tetap tinggi. Kalau di telaah secara kritis, kelemahan Bawaslu pada pilkada serentak 2015 adalah kesulitan memantau praktek politik uang, kelemahan mencari bukti-bukti otentik serta kesulitan membuktikan praktek money politic. Politik uang tersering hanya bisa dirasakan namun terkadang sulit untuk dibuktikan. Dibutuhkan kerja keras yang luar biasa untuk menekan semaraknya politik uang. Sumber daya yang mumpuni serta teknologi yang sangat cangih dibutuhkan untuk menjebak pelaku politik uang yang telah merusak kualitas demokrasi. 


\section{Rekrutmen Pencalonan Kepala Daerah}

Penyelenggaran pilkada serentak

2015 meninggalkan banyak kelemahan.

Rekruitmen penjaringan bakal pasangan calon

kepala daerah jauh dari semangat terbuka dan

transparan. Padahal dalam UU No. 8 Tahun

2015 tentang Pilkada dan UU No 2 Tahun

2011 tentang Partai Politik, meng-amanahkan

pilkada serentak dilaksanakan secara

demokratis dan jujur. Walaupun sudah

direkomendasikan kader terbaik oleh

pengurus partai daerah (DPD), namun kalau

kemudian tidak memperoleh surat sakti atau

rekomendasi dari pengurus pusat (DPP) maka

otomatis gagal mencalonkan diri menjadi

calon kepala daerah. Pengurus partai tingkat

pusat melalui rekomendasi DPP sangat

menentukan, sementara pengurus partai

tingkat daerah hanya formalitas. Sebetulnya

tidak relevan rekomendasi DPP terhadap

pendaftaran calon karena wilayah kontestasi

pilkada adalah di regional di Kabupaten/Kota

maupun Provinsi. Karena ini adalah

pertarungan di daerah maka menjadi otoritas

penuh pengurus partai di daerah.

Tidak ada rekomendasi DPP dalam mengusung calon dalam pilkada, melainkan dalam undang-undang pilkada Pasal 42 ayat 4 dan ayat 6 menyebutkan pendaftaran calon Gubernur dan Wakil Gubernur, calon Bupati dan Wakil Bupati, serta calon Walikota dan Wakil Walikota oleh parpol maupun gabungan parpol ditandatangani oleh para ketua parpol dan para sekretaris parpol di tingkat Provinsi atau para ketua parpol dan para sekretaris parpol di Tingkat

Kabupaten/Kota disertai surat keputusan masing-masing penggurus parpol di tingkat pusat tentang persetujuan atas calon yang diusulkan oleh pengurus parpol di tingkat provinsi dan/atau pengurus parpol tingkat kabupaten/kota.

Kalau kita cermati dari UU Pilkada di atas bahwa betapa besarnya kewenangan yang diberikan kepada pengurus partai di daerah dalam mengajukan calon kepala daerah dan pengurus parpol tingkat pusat hanya menyetujui pencalonan yang diusung parpol maupun parpol pendukung di daerah. Artinya DPP bukan memberikan 'rekomendasi' namun hanya konteks 'menyetujui'. Rekomendasi DPP yang seringkali disalahgunakan sebab salah satu determinan yang menentukan seseorang menjadi calon kepala daerah.

DPP seringkali mengintervensi proses pencalonan kepala daerah yang awalnya terbuka dan transparan oleh pengurus partai di daerah, lalu di bajak oleh rekomendasi DPP, inilah yang menjadi sabab musabab pencalonan kepala daerah menjadi tidak terbuka dan tidak demokratis, ujungnya memperluas wilayah titik sebaran perilaku transaksional dan pragmatisme dalam merekomendasikan pencalonan kepala daerah yang mau diusung oleh partai politik.

Jadi, kuatnya kendali DPP dalam menentukan pasangan calon disebabkan adanya ketentuan dalam Pasal 42 UU No 8 Tahun 2015 yang menyatakan pengajuan 
calon harus disertai surat keputusan DPP. Dengan adanya ketentuan ini, mayoritas yang berminat menjadi calon cukup berupaya mencari jalan pintas mendapatkan surat keputusan DPP. Namun perlu dipahami bahwa kewenangan partai tingkat pusat hanya mengeluarkan surat keputusan DPP dalam konteks menyetujui nama calon kepala daerah yang telah diusulkan oleh pengurus partai di daerah bukan memberikan rekomendasi terhadap pencalonan kepala daerah. ${ }^{90}$

\section{Dana Pilkada dari APBD?}

Dana penyelenggaraan pilkada serentak sebaiknya disediakan melalui pos Anggaran Pendapatan Belanja Negara (APBN), tidak tepat menggunakan Anggaran Pendapatan Belanja Daerah (APBD). Pengunaan APBD dalam penyelenggaraan pilkada serentak memungkinkan terjadinya "permainan" anggaran oleh kepala daerah dan DPRD karena berbeda kepentingan politik sehingga berkemungkinan APBD terlambat disahkan. Ketika APBD terlambat disahkan maka otomatis mengganggu rangkaian tahapan proses pilkada yang sudah disusun di beberapa daerah. Jadi, agenda strategis nasional seperti penyelenggaraan pilkada serentak, lebih tepat dibebankan ke APBN bukan ke APBD (Djohermansyah, 2016).

Sebuah konsekuensi logis dana pilkada yang dibebankan ke APBD bisa menggangu serangkaian tahapan proses

${ }^{90}$ Kompas. 17 Maret 2016. Ihwal Revisi UU Pilkada, hlm.6. pilkada serentak yang sudah disusun dan dijadwalkan. Pilkada di puluhan daerah berjalan seret sehingga mengganggu kelancaran tugas KPUD dan Bawaslu. Di beberapa daerah misalnya ada yang terkendala pengajuan Nota Perjanjian Hibah Daerah (NPHD) yang disebabkan oleh beberapa faktor seperti tahun anggaran yang sudah ketok palu, bertambahnya daerah yang ikut pilkada, sampai dengan adanya konflik kepentingan dari kepala daerah terkait penyelenggaran pilkada yang ikut berkontribusi menghambat proses pengajuan bahkan pencairan dana.

Belum lagi APBD sebesar delapan puluh persen tersedot untuk belanja rutin pegawai negeri sipil seperti gaji pegawai dan jauh lebih sedikit untuk pembangunan infrastruktur di daerah. Pelaksanaan pilkada serentak dibebankan ke APBD, secara tidak langsung dapat mengganggu pembangunan infrastruktur di daerah karena minimnya APBD di daerah. Selain itu, lembaga penyelenggara pilkada yakni KPU dan Bawaslu bersifat nasional bukan lokal. Bentangan emperis sebelumnya juga biaya penyelenggaraan pilkada serentak dibebankan ke APBN bukan ke APBD. Oleh karena itu, dana pelaksanaan pilkada serentak harus dikembalikan ke aturan sebelumnya.

\section{Sengketa Pilkada}

Putusan Mahkamah Konstitusi (MK) yang menolak mengadili sengketa hasil pilkada serentak jika selisih suara 2 persen 
lebih adalah putusan yang tidak tepat. Kebijakan tersebut memunculkan polemik, menuai protes dan melukai rasa keadilan. Ketentuan syarat selisih suara bagi setiap calon kepala daerah yang ingin mengajukan permohonan sengketa ke MK ini termaktub dalam Pasal 158 UU 8 Tahun 2015. Aturan ini terkesan menafikan tujuan keadilan pemilu itu sendiri, yakni suatu proses sengketa hasil pemilu di MK bukanlah persoalan angka dan hasil semata, tetapi juga harus memenuhi keadilan materiil.

Untuk sengketa hasil yang diajukan ke MK, syarat selisih tipis dengan kisaran 0,5 persen sampai 2 persen agar kembali ditinjau ulang, karena melukai rasa keadilan bagi calon. Di satu pihak memang sangat signifikan mengurangi jumlah gugatan, sehingga putusan MK tidak kejar tayang dalam setiap sidang sengketa pilkada. Di pihak lain, bagaimana kalau calon kepala daerah tersebut menang dengan penuh kecurangan dengan selisih lebih 2\%? Kalau MK tidak sanggup dan merasa keberatan menangani banyaknya berkas gugatan sengketa pilkada yang masuk ke MK, maka perlu segera diprioritaskan pembentukan badan peradilan khusus yang fokus mengawal peraturan perundang-undangan yang bertentangan dengan payung konstitusi UUD 1945.

Syarat selisih 0,5 persen- 2 persen harus dicabut kembali regulasinya karena ini jelas tidak sesuai dengan azaz keadilan. Logika sederhananya, tidak apa-apa melakukan kecurangan dalam pilkada asalkan selelisihnya lebih 2 persen, calon yang kalah akan gagal mengajukan gugatan ke MK karena tidak memenuhi syarat. Bukan tidak mungkin banyak calon yang menang pilkada tahun 2015 melakukan kecurangan sistematis, terstruktur dan masif sehingga selisih hasil suaranya jauh dari kontestan calon lain.

Selanjutnya, penyelesaian sengketa proses pilkada di PT-TUN hendaknya diberi batas waktu, seperti penyelesaian sengketa hasil di MK selama maksimal 45 hari. Kasus Pilkada 2015 di mana putusan PT-TUN yang berujung pada kasasi di MA memakan waktu lama sehingga pilkada serentak di lima daerah gagal dilaksanakan.

\section{Fenomena Calon Tunggal}

Putusan menetapkan PNS, TNI/Polri serta anggota DPR, DPD, dan DPRD wajib mundur saat penetapan pasangan calon kepala daerah. Konsekuensinya ada beberapa daerah mempunyai calon tunggal, artinya peserta calon kepala daerah yang berlaga dalam pesta demokrasi lokal (pilkada) hampir tidak ada pesaing karena calonnya tunggal, perebutan kursi kepala daerah minim kandidat. Sebuah justifikasi logis ketika kalah dalam kontestasi pilkada maka risiko besar menanti yakni tidak bisa kembali pada posisi jebatan semula, ada ketakutan dan tidak mau bunuh diri politik atau berjudi jabatan dengan mempertaruhkan kehilangan status PNS, anggota TNI/Polri, ataupun anggota Dewan 
ketika wajib harus mundur walaupun masih calon kepala daerah dan belum ditetapkan.

Untuk meminimalisir munculnya calon kepala daerah tunggal di beberapa daerah maka sebaiknya kembali pada regulasi atau aturan main sebelumnya yakni penetapan pasangan calon bagi PNS, TNI/Polri, anggota DPR, DPD, dan DPRD wajib mundur sejak ditetapkan sebagai pemenang kepala daerah/wakil kepala daerah terpilih, bukan saat penetapan pasangan pencalonan. ${ }^{91}$ Ini adalah satu strategi untuk mencegah munculnya calon tunggal. Dengan kembali pada aturan main lama maka hampir bisa dipastikan PNS, TNI/Polri, anggota DPR, DPD, dan DPRD akan ramai maju sebagai calon kepala daerah. ${ }^{92}$

Selain itu, fenomena munculnya calon tunggal pada kontestasi pilkada serentak tahun 2015 adalah disebabkan tingginya ambang batas dukungan parpol. Akibatnya parpol diborong oleh kandidat kuat sehingga muncul kasus daerah bercalon tunggal di beberapa daerah.

\section{Kesimpulan}

\footnotetext{
91 Menurut Djohermansyah Djohan, ambang batas perolehan kursi/suara parpol pengusung kandidat sebaiknya tetap mengacu angka minimal 20 persen dari jumlah kursi DPRD atau 25 persen dari akumulasi perolehan suara sah, untuk meminimalisir terlalu menjamurnya calon kepala daerah, ada yang jumlah calonnya sampai 13 pasangan. Kalau kita cermati dengan UU Pilkada lama, rata-rata jumlah calon yang berkontestasi 3-5 pasangan calon. Adapun batas "atas" ambang batas dukungan parpol untuk pencalonan sebaiknya tidak perlu diatur. Akan tetapi, yang perlu diatur adalah pemberian sanksi bagi parpol yang tidak mengajukan calon, misalnya melarang parpol tersebut mengajukan calon pada pilkada serentak berikutnya.

${ }^{92}$ Kompas. 11 Februari 2016. Merancang Pilkada yang Berkualitas, hlm.6.
}

Pilkada serentak telah berupaya menyederhanakan waktu pemilihan gubernur, bupati dan wali kota secara bersamaan dalam satu paket dengan semangat efisiensi demokrasi, dalam pengertian efisien dari sisi penggunaan anggaran dan efektif dari sisi penyelenggaraannya. Namun pilkada serentak pertama tahun 2015 belum mampu mencapai efisiensi anggaran. Begitu juga terkait pilkada serentak yang dari awal diharapkan mampu meningkatkan partisipasi pemilih namun faktanya tingkat partisipasi masih rendah.

Regulasi UU No. 8 Tahun 2015 belum mampu meminimalisir celah politik uang. Masih banyak laporan dugaan politik uang pada pilkada serentak 2015. Selain itu, pelaksanaan pilkada serentak perlu di evaluasi terutama terkait penjaringan calon kepala daerah yang dinilai masih belum terbuka dan demokratis. Surat rekomendasi DPP merusak semua mekanisme tahapan rekruitmen pencalonan kepala daerah. Nama calon yang diusulkan oleh pengurus partai daerah seringkali patah di tengah jalan dan pada akhirnya yang sangat menentukan adalah tetap rekomendasi DPP bukan pengurus partai di tingkat daerah. Sebuah anomali politik, bagaimana mungkin proses rekruitmen pencalonan bersifat terbuka dan demokratis sesuai kehendak amanat UU Pilkada, sementara pada waktu yang sama tumbuh dengan subur praktek persetujuan rekomendasi dari pengurus partai tingkat pusat yang justru sangat menentukan. 
Selanjutnya, pelaksanaan pilkada serentak dibebankan ke APBD jelas tidak tepat. Selama ini APBD sangat minim dalam pembangunan infrastruktur dan lebih tersedot untuk belanja rutin pegawai negeri sipil di daerah. Jangan sampai pemerintah pusat membebani daerah. Begitu juga putusan Mahkamah Konstitusi (MK) yang menolak mengadili sengketa hasil pilkada serentak jika selisih suara lebih dari dua persen. Kebijakan ini perlu ditinjau ulang kembali karena melukai rasa keadilan, bagaimana kalau selisih suara besar namun penuh dengan kecurangan? Substansi pelaksanaan pilkada serentak adalah demokrasi subtansial yang berkualitas. Kalau MK tidak siap menerima banyaknya berkas gugatan yang masuk ke MK, maka solusinya harus dibentuk peradilan khusus sengketa pilkada supaya MK bisa fokus mengawal konstitusi.

Pelaksanaan pilkada serentak tahun 2015 memunculkan fenomena calon tunggal di beberapa daerah. Untuk meminimalisir munculnya calon tunggal sebaiknya kembali pada aturan main sebelumnya yakni pasangan calon bagi PNS, TNI/Polri, anggota DPR, DPD, dan DPRD wajib mundur sejak ditetapkan sebagai pemenang kepala daerah/wakil kepala daerah terpilih, bukan saat penetapan pasangan pencalonan.

Penyelenggaraan pemilihan kepala daerah serentak tahun 2015 meninggalkan banyak catatan. Dibutuhkan perbaikan penyelenggaraan pilkada serentak dimulai dengan merevisi Undang-Undang Nomor 8
Tahun 2015 tentang Pemilihan Gubernur, Bupati, dan Wali Kota sehingga terwujudnya pilkada yang transparan, akuntabel, jujur dan demokratis.

\section{Daftar Pustaka}

Alifuddin, M. (2012). Panduan Praktis Perilaku Demokratis. MagnaScript Publishing.

Aminuddin dan A. Zaini Bisri (2005), Pilkada Langsung Problem dan Prospek Sketsa Singkat Perjalanan Pilkada 2005, Yogyakarta: Pustaka Pelajar.

Anggraini, T. 16 November 2015. Efisiensi penyelenggaraan Pilkada Serentak 2015 Belum Bisa Tercapai. (Online), http://www.republika.co.id/berita/nasi onal/pilkada/15/11/16/nxwawg335efisiensi-pilkada-serentak-belumtercapai, diakses 30 Maret 2016).

Asyari, H., \& Supriyanto, D. (2011). Menyederhanakan Waktu Pemilihan Umum. Pemilu Nasional dan Pemilu Daerah.

Bawaslu. 14 Desember 2015. Bawaslu Malut Terima 79 Laporan Dugaan Money Politic. (Online), (http://www.jpnn .com/read/2015/12/14/344509/Bawasl u-Malut-Terima-79-Laporan-DugaanMoney-Politic-, diakses 4 April 2016).

Edwin, D. (2005). Pilkada langsung: demokratisasi daerah dan mitos good governance. Kerjasama Partnership for Governance Reform in Indonesia 
dengan Pusat Kajian Politik,

Departemen Ilmu Politik, Universitas Indonesia.

Harris, Syamsuddin (2005), 'Pilkada Langsung dan Masa Depan Otonomi Daerah.' Jurnal Politika, Vol. 1, No. 1.

Hasyim Asyari dan Didik Supriyanto. Menyederhanakan Waktu Pemilihan Umum. Pemilu Nasional dan Pemilu Daerah (2011), Jakarta: Kemitraan Bagi Tata Pembaruan Pemerintahan.

Hoessein, Bhenyamin (1997), 'Tantangan Global dan Tanggap Lokal: Desentralisasi Demokrasi dan Efisiensi.' Manajemen Pembangunan, No. $19 / \mathrm{V}$.

Isra, Saldi. 17 Maret 2016. Ihwal Revisi UU Pilkada. Kompas, hlm.6.

Koalisi Masyarakat Sipil Untuk Revisi Undang-Undang Pilkada. (2015). Menuju Pilkada Serentak Nasional 2021. Perludem.

Kompas. 17 Maret 2016. Ihwal Revisi UU Pilkada, hlm.6.

Lay, C. (2007). Pilkada Langsung dan Pendalaman Demokrasi, Jurnal Ilmu Sosial dan Ilmu Politik, Vol. 11, No 1.

Marijan, Kacung (2006), Demokratisasi di Daerah: Pelajaran Pilkada Secara Langsung, Surabaya: Pustaka Eureka.

Ma'riyah, C. (2012). Menggugat Politik Dinasti Dalam Pemerintahan
Indonesia. Jurnal Ilmu Pemerintahan.

Edisi, 36.

Panwas. 18 Desember 2015. 7 kasus dugaan politik uang pilkada seluma diproses gakkumdu. (Online), (http://www. beritasatu.com/nasional/333138-7kasus-dugaan-politik-uang-pilkadaseluma-diproses-gakkumdu.html, diakses 2 April 2016)

.Roni Lukum, Pilkada Langsung Dan Implikasinya Terhadap Perubahan Perilaku Masyarakat Dalam Menuju Pembangunan Demokrasi di Indonesia.

Samuels, D. (2000). Concurrent elections, discordant results: presidentialism, federalism, and governance in Brazil. Comparative Politics, 1-20.

Supriyanto, D., Agustyati, K., \& Mellazt, A. (2013). Menata Ulang Jadwal Pilkada: Menuju Pemilu Nasional dan Pemilu Daerah.

Suparjana (2012), Qua Vadis Pemilihan Kepala Daerah Secara Langsung, Jurnal Ilmu Pemerintahan, Politik Dinasti dan Implikasinya Terhadap Praktek Pemerintahan, Edisi: 36.

Zuhro, S. (2012). Memahami Demokrasi Lokal: Pilkada Tantangan dan Prospeknya, Jurnal Perludem. 